\title{
Molecular analysis of Brachidonte spharaonis (Fischer P., 1870) in Egypt reveals cryptic species complex.
}

\author{
Nancy A. Radwan ${ }^{1}$; Mohammed I. Ahmed ${ }^{2}$, Nesreen K. Ibrahim², Saad Z. \\ Mohammed $^{2}$ and Zakaria S. Morsy ${ }^{1}$ \\ 1- Department of Zoology, Faculty of Science, El Arish, Suez Canal University, Egypt. \\ 2- Department of Marine Science, Faculty of Science, Ismailia, Suez Canal University, Egypt.
}

\section{ABSTRACT}

Species and genetic diversity of the migrant Brachidonte spharaonis bivalve were studied along the Egyptian waters in order to determine the phylogenetic status of the species and to detect speciation with geographical isolation. Samples were collected from the Red Sea, Mediterranean Sea and Suez Canal. Genetic diversity was estimated using the DNA barcoding technique for mitochondrial CO1 gene. The DNA barcoding results showed that $B$. pharaonis collected from different localities were clustered in different clades indicating that the $B$. pharaonis population in the Egyptian coasts might form a cryptic species complex rather than a population of one species. These results may have a great impact on the conservation and fisheries status of $B$. pharaonis in the Egyptian waters.

Keywords: Brachidontespharaonis, DNA barcoding, Cryptic species, CO1.

\section{INTRODUCTION}

Suez Canal is considered to be the shortest link between the east and the west due to its unique geographic location between the Mediterranean Sea at Port Said and the Red sea at Suez, Egypt. The opening of Suez Canal in 1869, initiated the invasion of marine species, usually from the Red Sea to the Mediterranean Sea "Lessepaisn migration" (Por, 1978) and more rarely in the opposite direction. Biological invasion have recently become an important issue both in conservation as well as in theoretical ecology (Holland, 2000), that invasion pose a great threat to the integrity of natural communities; alter the ecosystem dynamics and world-wide community structure (Doğan et al., 2007). Brachidonte spharaonis (Fischer, 1870) is one of these invasion species that able to migrate and colonies through the Suez Canal.

B. pharaonis is a lessepsian mussel and one of the earliest Erythrean invaders to the Mediterranean Sea (Rilov and Galil, 2009). It originally from the Indo-Pacific area mainly South-Eastern Asia, that colonized the Mediterranean Sea via the Suez Canal,settles in dense clusters on midlittoral rocky habitats (Terranova et al., 2006), and competes for space and food with its Mediterranean ecological equivalent Mytilaster minimus (Safriel et al., 1980). It iswidely distributed; the first collection from the Mediterranean Sea was from Port Said, Egypt in 1876 (Pallary, 1912), and was not recorded in the Mediterranean before opening the Suez Canal (Issel, 1869); along the Red Sea coasts of Egypt (Shefer et al., 2004); successively found in Lebanon; Israel (Sara' et al., 2008); Italy; Greece; Syria; Southern Turkey; northern Cyprus; Croatia (Barash \& Danin, 1992); Eritrea and Sri Lanka (Shefer et al., 2004). In the recent warming trend of the Mediterranean Sea, (in the future), B. pharaonis may actively invade more habitats, threating indigenous bivalve species which may 
unable to compete with it in terms of reproductive effort and density (Sara'et al., 2008).

Primarily identification of Brachidontes depends on morphological characters but the high degree of morphological variation makes identification and systematic studies more difficult, and potentially hides cryptic species, compelling a search for systematic characters not influenced by environmental variations (Terranova et al., 2007). Recently, the mtDNA variation is used to describe the population structure of B. pharaonis and to make inference about its invasion of the Mediterranean Sea. DNA barcode is the use of short, standardized gene for species identification (Hebert et al., 2004). In this study the mitochondrial DNA gene cytochrome c oxidase subunit 1 (CO1) was used as a universal barcoding marker for identifying and describing the population structure of $B$. pharaonis in Egypt.

The main objective in this study is to investigate the molecular diversity of $B$. pharaonisin different locations from the Mediterranean Sea to the Red Sea and study the effect of environmental and ecological differences between the two seas on the formation of cryptic species.

\section{MATERIALS AND METHODS}

\section{Study areaandSample collection}

Brachidonte spharaonis mussels were collected from five locations along the Egyptian costal shores: Mediterranean Sea (Port Said), North Sinai (Lake Bardawil), Suez Canal (Lake Timsah), Suez (Gulf of Suez), and Red Sea (Marsa Alam) during 2012-2013 (Fig. 1).Samples were collected by scrapping the rocky surface on the beaches.

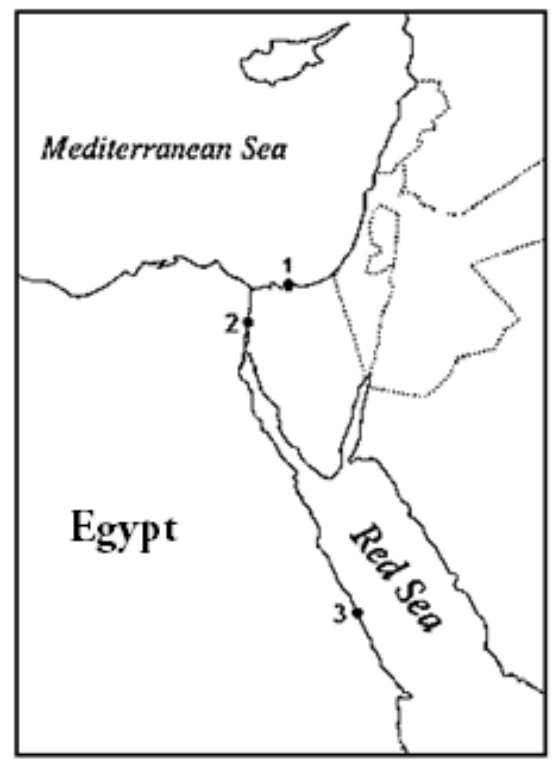

Fig. 1: Map showing the sites of collection ofBrachidontespharaonis 1: Lake Bardawil; 2: Port Said; 3 : Lake Timsah; 4: Gulf of Suez; 5: MarsaAlam.

\section{Morphological examinations}

The B. pharaonis specimens were chosen randomly from each site andthen identified according to Sharabati (1984) for morphological examination (shell characters \&colour). 


\section{Molecular studies gDNA Extraction, PCR amplification and sequencing}

The samples were frozen at $-70^{\circ} \mathrm{c}$ and the gDNA was extracted froma very small piece of foot using the phenol-chloroform (CTAB) procedure as described by Coffroth et al. (1992), and then the DNA was stored at $-20^{\circ} \mathrm{c}$. A small region $(\sim 600-$ 700 bps) of the mitochondrial CO1 gene was amplified in the thermocycler (Major Science Thermocycler) using the universal primers described by Folmer et al. (1994):

LCO1490 (F): 5'-GGTCAACAAATCATAAAGATATTGG-3'.

HCO2198 (R): 5'-TAAACTTCAGGGTGACCAAAAAATCA-3'.

PCR reaction was performed in $25 \mu 1$ volume containing $12.5 \mu 1$ Master Mix, $0.5 \mu \mathrm{l}$ of each primer $(10 \mathrm{pmol}), 6 \mu \mathrm{l}$ of template DNA (about 100 ngtemplate DNA)and sterile distilled water to final volume of $25 \mu 1$.To optimize PCR products, annealing temperature and times were varied. PCR conditions were as follows: an initial denaturation for $3 \mathrm{~min}$ at $94{ }^{\circ} \mathrm{c}$, followed by $45 \mathrm{sec}$ at $94{ }^{\circ} \mathrm{c}, 1 \mathrm{~min}$ at annealing temperature $52^{\circ} \mathrm{C}$ and $2 \mathrm{~min}$ at $72^{\circ} \mathrm{C}$ for 35 cycles, and a final extension of $5 \mathrm{~min}$ at $72{ }^{\circ} \mathrm{c}$.

The PCR products were run on a $1.5 \%$ horizontal agarose gel stained with ethidium bromide. The bands were visualized and photographed in UV photo documentation unit. Purification was carried out by using (QIAquick PCR Purification Kit, QIAGEN). The purified PCR product was sequenced in Macrogen Ltd (Korea) and Biotechnology Research Center (Suez Canal University, Egypt) by (3500 Genetic Analyzer, Applied Biosystems).

\section{Phylogenetic analysis}

Sequence chromatograms of COlsequences were edited for all taxa using MEGA V6.06 software and aligned using the Clustal W program then adjusted manually. The dataset for 15 specimens of $B$. pharaonis in the present study with their accession number on GenBank are described in Table (1).

Table 1: Brachidontes sp. individuals included in analysis, with their collection localities, ID and GenBank accession number.

\begin{tabular}{|c|c|c|c|}
\hline Species & Locality & ID & Accession number \\
\hline \multirow{15}{*}{ Brachidontes pharaonis } & \multirow{3}{*}{$\begin{array}{l}\text { Mediterranean Sea } \\
\text { Lake Bardawil }\end{array}$} & 1 & KP164519 \\
\hline & & 2 & KP164520 \\
\hline & & 3 & KP164521 \\
\hline & \multirow{3}{*}{$\begin{array}{c}\text { Mediterranean Sea } \\
\text { Port Said }\end{array}$} & 4 & KP164522 \\
\hline & & 5 & KP164523 \\
\hline & & 6 & KP164524 \\
\hline & \multirow{3}{*}{$\begin{array}{c}\text { Suez Canal } \\
\text { Lake Timsah }\end{array}$} & 7 & KP164525 \\
\hline & & 8 & KP164526 \\
\hline & & 9 & KP164527 \\
\hline & \multirow{3}{*}{$\begin{array}{c}\text { Suez } \\
\text { Gulf of Suez }\end{array}$} & 10 & KP164528 \\
\hline & & 11 & KP164529 \\
\hline & & 12 & KP164530 \\
\hline & \multirow{3}{*}{$\begin{array}{c}\text { Red Sea } \\
\text { Marsa Alam }\end{array}$} & 13 & KP164531 \\
\hline & & 14 & KP164532 \\
\hline & & 15 & KP164533 \\
\hline
\end{tabular}

Using Blast, $C O 1$ sequences of the most related species of $B$. pharaonis were screened on the NCBI GenBank data base and then added to the present analysis to construct phylogenetic tree using MEGA 6 (Tamura et al., 2013) to test the presence of cryptic sibling species. Mytilaste rminimus (DQ836022) and Geukensia demissa (U56844) were used as outgroups with bootstrap value 100\%. 
The phylogenetic relationship between $B$. pharaonis from Egypt and other Brachidontes species on GenBankwas constructed according to the lowest Bayesian Information Criterion (BIC) using the substitution model $(\mathrm{HKY}+\mathrm{G}+\mathrm{I})$.NeighborJoining tree based on p-distance was constructed for the phylogenetic relationship between $B$. pharaonis in the present studyand 29 members of $B$. pharaonis obtained from GenBank (collected along the Mediterranean and Red Sea). To construct a phylogenetic relationship between $B$. pharaonis individuals collected from the five populations, Maximum likelihood tree was constructed with the $(\mathrm{HKY}+\mathrm{I})$ model.

\section{RESULTS}

\section{Morphological examinations}

Using of morphological characters to identify $B$. pharaonis from different locations revealed that no significant differences were found between the individuals in all populations.

\section{Phylogenetic analysis}

As shown in Fig. (2), DNA barcoding was successfully able to distinguish between Brachidontes species in the current study and different species of Brachidontes obtained from GenBank. The phylogenetic tree shows that $B$. pharaonis from all sites in Egypt were clustered together with B. pharaonis from GenBank (AY129565) with high bootstrap value (100\%) and diverged from B. variabilis with low bootstrap value.
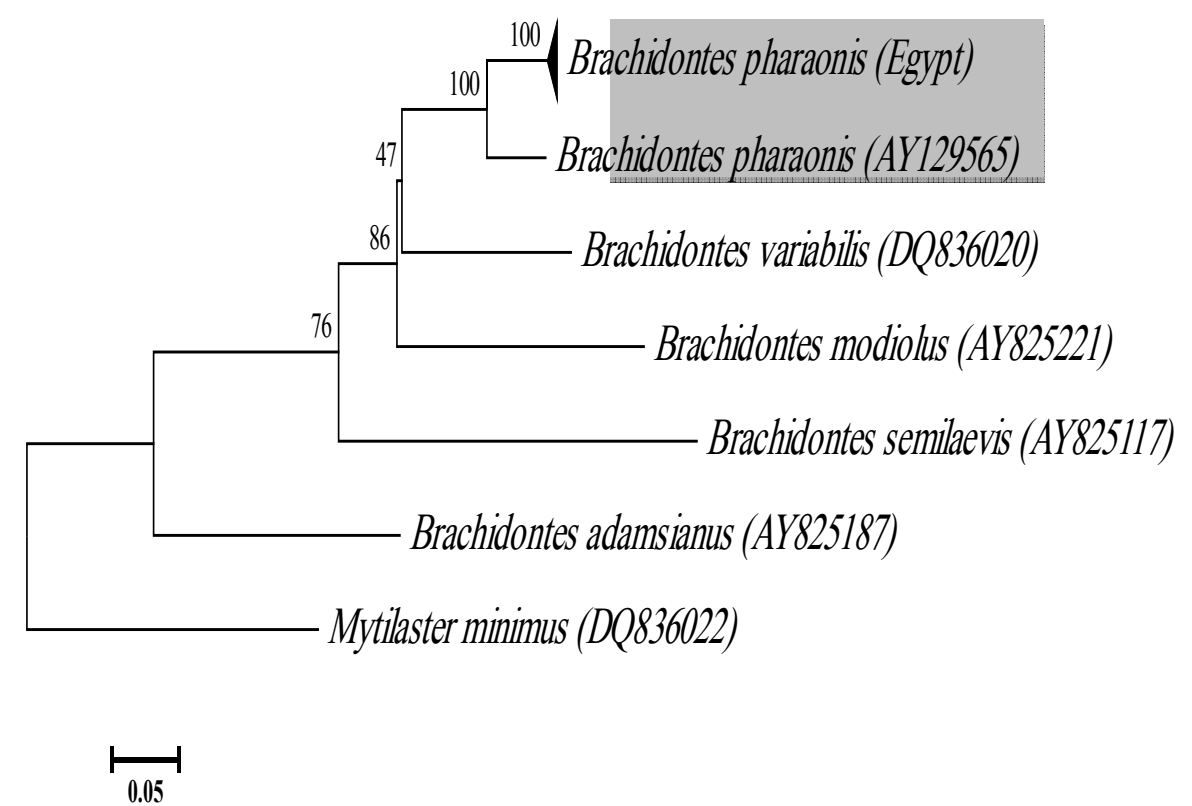

Fig. 2: A Maximum Likelihood tree for $C o 1$ sequences of individuals of $B$. pharaonis collected from Egypt and different species of Brachidontes obtained from GenBank. Internal branches within species from Egypt were compressed. Mytilaster minimus was used as outgroup with bootstrap value $(100 \%)$.

Neighbor-Joining tree (Fig. 3) illustrates the phylogenetic relationships between 15 individuals in the present study and 29 individuals obtained from GenBank. The tree revealed that individuals from Egypt are clustered together with other B. pharaonies obtained from GenBank, which represented Brachidontes 
collected along the Mediterranean and Red Sea, showing closely phylogenetic relationship between the all individuals supported by low bootstrap values at the internal nodes.

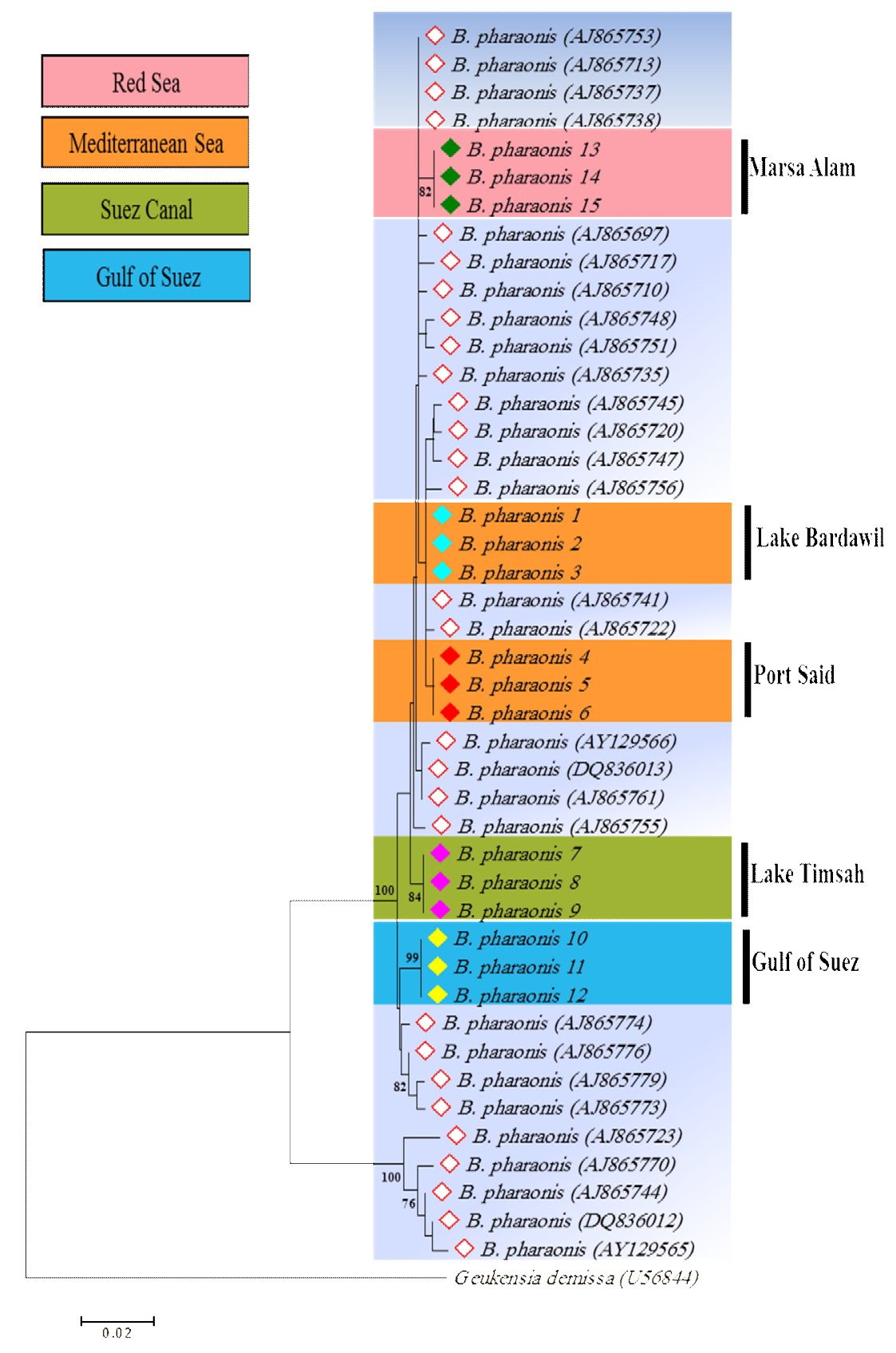

Fig. 3: Neighbor-Joining Tree forCol sequences of B. pharaonisin the current study and sequences of Brachidontes individuals obtained from GenBank. Geukensia demissa was used as outgroup. Only bootstrap value $>75 \%$ are shown.

Maximum likelihood tree (Fig. 4) represented the phylogenetic relationship between all individuals of $B$. pharaonis in the current study. The phylogenetic analysis revealed that $B$. pharaonisfrom different sites formed clusters with no samples falling on other sites revealing that Brachidonte spharaonis in Egypt might form a combination of cryptic species complex rather than one species. 


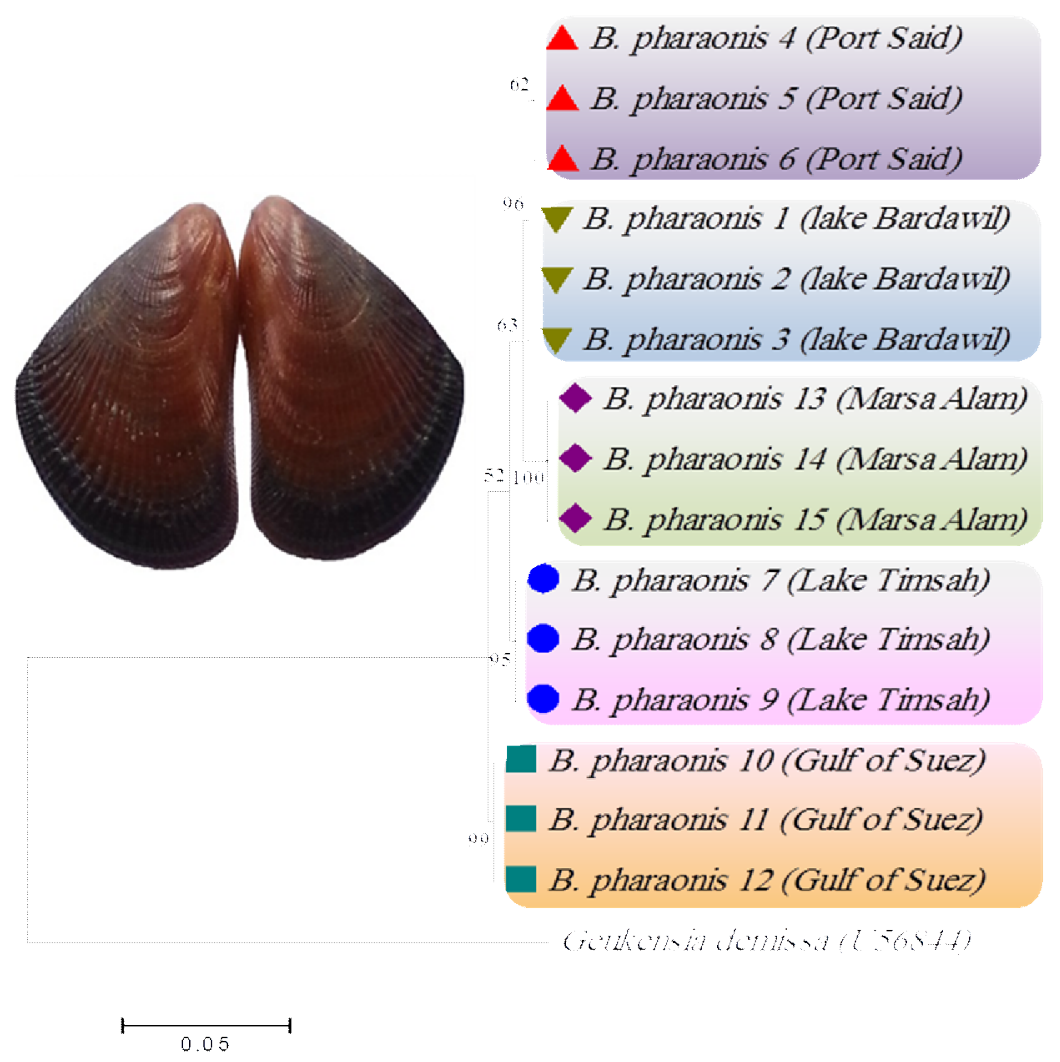

Fig. 4: Maximum Likelihood Tree for $C O 1$ sequences of $B$. pharaonis collected from 5 different habitats along the Egyptian costal shores. Geukensia demissa was used as outgroup with bootstrap value $(100 \%)$.

\section{DISCUSSION}

Using of morphological examinations in identification of Brachidontes individuals showing that there is no significant differences between all samples collected from the five sites along the Egyptian coasts (Lake Bardawil, Port said, Lake Timsah, Gulf of Suez, Marsa Alam), where the morphological characters were not obvious enough to distinguish between individuals from the different populations. The main problem in using morphological characteristics in species identification is the difficulty to measure the point at which the similarity/difference is taken to indicate taxa (Baker and Bradley, 2006).

Due to different interpretations of the high variability of the shell characters, many authors (Arcidiacono and Di Geronimo, 1976; Chemello and Oliverio, 1995; Gianguzza et al., 1997; Rilov et al., 2002) have used B. pharaonis as a synonym of $B$. variabilis (Krauss, 1848), and this causes a big ambiguity for the Mediterranean Sea and the Red sea regions.

Meanwhile, the simplicity and clarity of gDNA extraction; PCR amplification and sequencing techniques used in DNA barcoding were found to overcome the morphological examination problems that can lead to incorrect identification.

CO1 proving highly effective in identifying large groups of animals (Hebert et al., 2003), successfully applied to a variety of taxa (e.g. birds, Hebert et al., 2004; crustaceans, Lefebure et al., 2006; fungi, Seifert et al., 2007; mammals, Hajibabaei et al., 2007; amphibians, Smith et al., 2008; fish, Zhang and Hanner, 2011; mollusks, Feng et al., 2011) in the past few years. 
In the present study, our molecular results showed that Brachidonte spharaonis and Brachidontes variabilis formed different distinct clades. Adding to that, using of DNA barcoding revealed that the Brachidontes species found in Egypt is B. pharaonis and that is contrasted with Kandeel (1992) who identified Brachidontes as Brachidontes variabilis, and matched the identification of (Shefer et al., 2004) who identified the Egyptian population as Brachidonte spharaonis. Likewise, Terranova et al. (2007) stated that the systematic revision of the taxon $B$. variabilis is needed and the name of $B$. pharaonis is most appropriate for the species in the Mediterranean Sea and the Red Sea.

In the marine realm, climatic changes have shifted the chemical and biological properties of many marine systems and the geographical distances are associated with the temperature and salinity gradients (Lo Brutto et al., 2011). The ecological plasticity of Brachidontes has likely played an important role in the persistence of $B$. pharaonis in the Mediterranean coasts (Apte et al., 2000).

In the current study, B. pharaonies collected from different localities formed distinct clades; therefore they are not a one species complex but rather a cryptic species complex. The formation of cryptic species complex in Egypt might be related to the geographical distance between the sites and different ecological habitats from which samples were collected. This result reported a similar result: the taxon previously recognized as B. exustus is composed of four cryptic species (Lee and O' Foighil, 2004). As like, Shefer et al. (2004) revealed two well-differentiated clades within B. pharaonis on the Mediterranean coast of Israel, in the Gulf of Suez, and in the northern Red sea using the mitochondrial CO1 gene. Terranova et al. (2007) by using Genetic analysis on Brachidontes samples in the Caribbean revealed three welldifferentiated clades identifying three cryptic species.

All these findings of phylogenetic analysis provides the formation of cryptic species but not support the formation of separated species, this could be attributedto that the time from the invasion of the indo-Pacific $B$. pharaonis from Red Sea to Mediterranean Sea is no longer enough for the changing in the genetic structure and reproduction to form a new species. This is agreed with Shefer et al. (2004) who stated that the time frame for the Mediterranean invasion by B. pharaonis is $<150$ years (Por, 1978; Safriel et al., 1980), while the average rate of its expansion eastwards from the Canal's Mediterranean end was $\sim 10 \mathrm{~km} /$ year and it's only in the past 30 years that a dramatic increase in population size has been reported (Safriel et al., 1980; Rilov et al., 2001). This time frame is undoubtedly not long enough for reproductive isolation and a high proportion of uniqueness (up to $80 \%$ ) to evolve.

Finally this study showed that the use of morphological characters in the identification of marine bivalve was not accurate enough in species identification and was not able to discover cryptic or hybrid species complex. The use of DNA barcoding in the identification of Brachidontes in Egypt revealed that the Egyptian population of Brachidontes is formed by the species B. pharaonis not B. variabilis as previously thought. The results also revealed a cryptic species complex of five cryptic species located in different areas. Our results may have a great impact on the conservation and fisheries management, in addition to species diversity of the Egyptian waters, and highlight the need for further research on species complexes and migrated species. 


\section{REFERENCES}

Apte, S.; Holland, B. S.; Godwin, L. S. and Gardner, J. P. A. (2000). Jumping ship: a stepping stone event mediating transfer of a nonindogenous species via a potentially unsuitable environment. Biol. Invasions, 2: 75-79.

Arcidiacono, A. and Di Geronimo, I. (1976). Studio biometrico di alcunicampioni di Brachidontesvariabilis (Krauss). Conchiglie, 12:61-74.

Baker, R. J. and Bradley, R. D. (2006): Speciation in Mammals and the Genetic species concept. J. Mammal., 87(4):643-662.

Barash A. and Danin, Z. (1992). Fauna Palaestina: Mollusca I. Annotated list of Mediterranean molluscs of Israel and Sinai. Israel Acad. Sci. Human., Jerusalem.

Chemello, R. and Oliverio, M. (1995). Lessepsian migrations: a theoretical islandjumping- model. Biol. Mar. Medit., 3: 444-446.

Coffroth, M. A.; Lasker, H. R.; Diamond, M. E.; Bruenn, J. A. and Bermingham, E. (1992). DNA fingerprints of a gorgonian coral: a method for detecting clonal structure in a vegetative species. Mar. Biol., 114 (2): 317-325.

Doğan, A.; Önen, M. and Öztürk, B. (2007). A new record of the invasive Red Sea mussel Brachidontes pharaonis (Fischer P., 1870) (Bivalvia: Mytilidae) from the Turkish coasts. Aquat. Invasions, 2 (4): 461-463.

Feng, Y.; Li, Q.; Kong, L. and Zheng, X. (2011). CO1-based DNA barcoding of Arcoida species (Bivalvia: Pteriomorphia) along the coast of China. Mol. Ecol. Res., 11: 435-441.

Folmer, O.; Black, M.; Hoeh, W.; Lutz, R. and Vrijenhoek, R. (1994). DNA primers for amplification of mitochondrial cytochrome c oxidase subunit 1 from diverse metazoan invertebrates. Mol. Mar. Biol. Biotechnol., 3: 294 - 229.

Gianguzza, P.; Chemello, R. and Riggio, S. (1997). Segnalazione di Brachidontes pharaonis (P. Fischer, 1870) (Bivalvia, Mytilidae) nellasalina di Marsala e considerazioni sulla distribuzione della specie in Mediterraneo. Boll Malac 33:169-172.

Hajibabaei, M.; Singer, G. A. C.; Hebert, P. D. N. and Hickey, D. A. (2007). DNA barcoding: how it complements taxonomy, molecular phylogenetics and population genetics. TrendsGenet., 23 (4): 167-172.

Hebert, P.D.N.; Cywinska, A.; Ball, S. L. and de Waard, J. R. (2003), Biological identifications through DNA barcodes. Proc. R. Soc. Lond. (B) Biol. Sci., 270:313-321.

Hebert, P. D. N.; Stoeckle, M. Y.; Zemlak, T. S. and Francis, C. M. (2004). Identification of birds through DNA barcodes, Plos. Biol. 2 (10) 1657-1663.

Holland, B. S. (2000). Genetics of marine bioinvasions. Hydrobiologia 420: 63-71.

Issel, A. (1869). Malacologiadel Mar Rosso, Pisa pp 387.

Kandeel, S. K. (1992). Biological studies on the reproduction of some bivalves in Lake Timsah. M.Sc. Thesis, Fac. Sci. Suez Canal Univ., Ismailia, Egypt.

Lee, T. and O' Foighil, D. (2004). Hidden Floridian biodiversity: mitochondrial and nuclear gene trees reveal four cryptic species within the scorched mussel, Brachidontes exustus, species complex. Mol. Ecol., 13:3527-3542.

Lefebure, T.; Douady, C.J.; Gouy, M. and Gibert, J. (2006). Relationship between morphological taxonomy and molecular divergence within crustacea: proposal of a molecular threshold to help species delimitation. Mol. Phylogenet. Evol., 40: 435-447. 
Lo Brutto, S.; Arculeo, M. and Grant, W. S. (2011). Climate change and population genetic structure of marine species. Chem. Ecol., 27 (2): 107-119.

Pallary, P. (1912). Catalogue des mollusques du littoral méditerranéen de l'Egypte. Mémoires de l'Institutd'Egypte, 7: 69-207, pl. 15-18.

Por, F.D. (1978). Lessepsian migrations: The influx of Red Sea biota in to the Mediterranean by way of the Suez Canal. Heidelberg: Springer. 228p.

Rilov, G. and Galil, B. (2009). Marine bioinvasions in the Mediterranean SeaHistory, distribution and Ecology. Biological invasions in Marine Ecosystems, Ecolo. Stud., 204.

Rilov, G.; Benayahu, Y. and Gasith, A. (2001). Low abundance and skewed population structure of the whelk Stramonitab haemastoma alongthe Israeli Mediterranean coast. Mar. Ecol. Prog. Ser., 218, 189-202.

Rilov, G.; Gasith, A. and Benayahu, Y. (2002). Effect of an exotic prey on the feeding pattern of a predatory snail. Mar. Envir. Res., 54:85-98.

Safriel U. N.; Felsenburg, T. and Gilboa, A. (1980). The distribution of Brachidontes variabilis (Krauss) along the Red Sea coasts of Sinai. Argamon, 7(3): 31-43.

Sara', G.; Romano, c. and Mazzola, A. (2008). Anew Lessepsian species in the western Mediterranean (Brachidonte spharaonis Bivalvia: Mytilidae): density, resource allocation and biomass. Mar. Biodiv.Record.,1, (e8).

Seifert, K. A.; Samson, R. A.; Dewaard, J. R.; Houbraken, J.; Lévesque, C. A.; Moncalvo, J. M.; Louis-Seize, G. and Hebert, P. D. N. (2007). Prospects for Fungus identification using CO1 DNA barcodes, with Penicillium as a test case. Proc. Natl. Acad. Sci., U.S.A., 104: 3901-3906.

Sharabati, D. (1984). Red sea Shells. KPI limited, London. 122pp.

Shefer, S.; Abelson, A.; Mokady, O.and Geffen, E. (2004). Red to Mediterranean Sea bioinvasion: natural drift through the Suez Canal, or anthropogenic transport. Mol. Ecol., 13:2333-2343.

Smith, M. A.; Poyarkov, N. A. and Hebert, P. D. N. (2008). DNA barcoding amphibians: take the chance, meet the challenge. Mol. Ecol. Resour., 8: 235246.

Tamura, K.; Stecher, G.; Peterson, D.; Filipski, A. and Kumar, S. (2013). MEGA6: Molecular Evolutionary Genetics Analysis version 6.0. Mol. Biol. Evol., 30: 2725-2729.

Terranova, S. M.; Brutto, L. S.; Arculeo, M. and Mitton, J. B. (2006). Population structure of Brachidonte spharaonis (P. Fischer, 1870) (Bivalvia, Mytilidae) in the Mediterranean Sea, and evolution of a novel mtDNA polymorphism. Mar. Biol., 159:89-101.

Terranova, S. M.; Brutto, L. S.; Arculeo, M.; Mitton, J. B. (2007). A mitochondrial phylogeography of Brachidontes variabilis (Bivalvia: Mytilidae) reveals three cryptic species. J. Zool. Syst. Evol. Res., 45(4): 289-298.

Zhang, J. B. and Hanner, R. (2011). DNA barcoding is a useful tool for the identification of marine fishes from Japan. Biochem. Syst. Ecol., 39: 31-42. 


\section{ARABIC SUMMARY}

دراسات جزيئية على براكيدونتس فاراؤنيز فى مصر تكثف مجموعة من الأنواع المبهمة

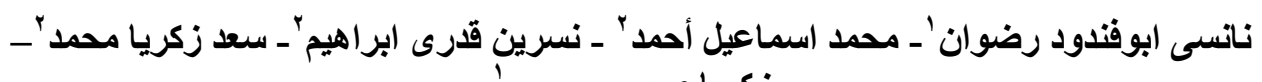

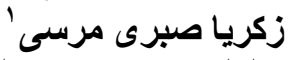

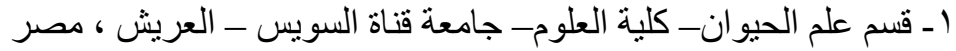

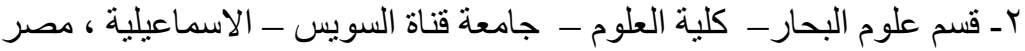

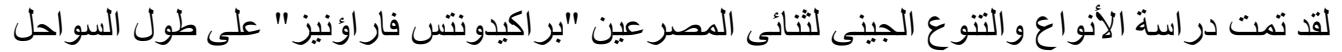

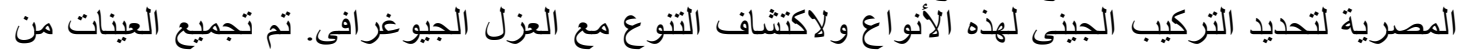

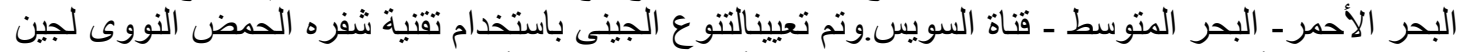

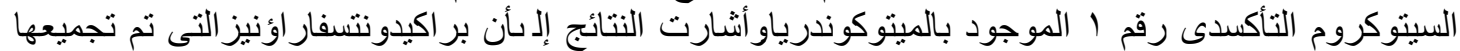

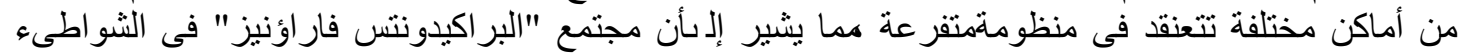

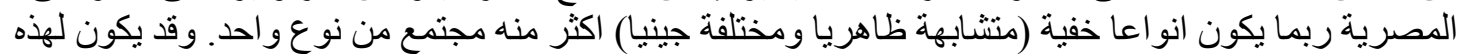
النتائج تأثثر كبير فى الحفاظ على بر اكيدونتس فار اؤنيز فى المياه المصريها. 